\title{
Productivity and chemical quality of grapevines cultivated in agroecological system under subtropical climate
}

\begin{abstract}
Josiane Aparecida Mariani ${ }^{1}$ \& Gilmar Antônio Nava²
Abstract - The productive potential of grapevine cultivars recently released in the market, especially for preparation of $100 \%$ grape juices, must be proved on the different Brazilian soil and climatic conditions of production, focusing on the Southwest of Paraná. The objective of this study was to evaluate the main yield components and chemical attributes of the juice of the following grapevine cultivars: Bordô, BRS Carmem, BRS Lorena, BRS Magna, BRS Rubea, BRS Violeta, Concord, Concord Clone 30, Isabel, Isabel Precoce, Moscato Bailey, Moscato Embrapa, Niagara Branca, Niagara Rosada and Seibel 5455. Paulsen 1103 was the rootstock used. The study was conducted during two harvests, 2015/2016 and 2016/2017, in Dois Vizinhos, Paraná State, Brazil. Due to the crop, we determined the number of bunches per plant, fresh biomass of bunches ( $\mathrm{g}$ ) and the estimates of productivity ( $\mathrm{kg} / \mathrm{plant}$ and ton/ha). We extracted the juice of cultivars to evaluate soluble solids (SS) contents, $\mathrm{pH}$ and titratable acidity (TA), as well as the ratio. The cultivars BRS Violeta, Isabel Precoce and Seibel 5455 were the most productive. The cultivars BRS Rúbea, BRS Violeta, Isabel, Moscato Embrapa, Moscato Bailey, Niagara Branca and Niagara Rosada have desirable soluble solids contents, $\mathrm{pH}$ and titratable acidity for preparation of $100 \%$ grape juices of quality in Dois Vizinhos and microregion. The best year-harvest of cultivation was 2016/2017. Index terms: Vitis labrusca, hybrid, chemical quality and productivity.
\end{abstract}

\section{Produtividade e qualidade química de uvas de videiras cultivadas no sistema agroecológico em clima subtropical}

Corresponding author: josiane_mariani@hotmail.com

Received: May 04, 2017.

Accepted: July 02, 2018.

Copyright: All the contents of this journal, except where otherwise noted, is licensed under a Creative Commons Attribution License.

\section{(cc) $\mathbf{E Y}$}

Resumo - O potencial produtivo de cultivares de videiras mais recentemente lançadas no mercado, principalmente para elaboração de suco integral, precisa ser comprovado nas distintas condições edafoclimáticas brasileiras de produção, incluindo o Sudoeste do Paraná. Assim, o objetivo deste trabalho foi avaliar os principais componentes de rendimento e atributos químicos do mosto das seguintes cultivares de videiras: Bordô, BRS Carmem, BRS Lorena, BRS Magna, BRS Rúbea, BRS Violeta, Concord, Concord Clone 30, Isabel, Isabel Precoce, Moscato Bailey, Moscato Embrapa, Niagara Branca, Niagara Rosada e Seibel 5455. O porta-enxerto usado foi o Paulsen 1103. O trabalho foi realizado durante duas safras, 2015/2016 e 2016/2017, em Dois Vizinhos-PR. Por ocasião da colheita, foram determinados o número de cachos por planta, a massa fresca de cachos (g) e as estimativas de produtividade (kg/planta e t/ha). Extraiu-se o suco das cultivares para a realização da avaliação dos teores de sólidos solúveis (SS), pH e acidez titulável (AT), bem como a relação SS/AT. As cultivares BRS Violeta, Isabel Precoce e Seibel 5455 foram as mais produtivas. As cultivares BRS Rúbea, BRS Violeta, Isabel, Moscato Embrapa, Moscato Bailey, Niagara Branca e Niagara Rosada apresentam teores de sólidos solúveis, pH e acidez desejáveis para a elaboração de sucos integrais de qualidade em Dois Vizinhos e microrregião. O melhor ano-safra de cultivo foi 2016/2017.

Termos para indexação: Vitis labrusca, híbridos, qualidade química e produtividade. 


\section{Introduction}

In $2015,1,499,353$ tons of grapes were produced within a cultivated area of 77,786 hectares in Brazil (IBGE, 2015). Vitiviniculture is an important activity for the sustainability of small properties in Brazil and has become equally relevant both in wine and juice productions, as in other economic activities related to tourism and gastronomy, which are important to the sustainability of family farms (MELLO, 2017).

The commercial viticulture in Paraná began in the 1940s and, currently, the state is the $4^{\text {th }}$ largest grape producer in the country, behind only of Rio Grande do Sul, Pernambuco and São Paulo. With a production of 80 thousand tons of grapes in 4,800 hectares in the last harvest, Paraná was one of the states that had a drop in production, due to climatic factors and reduction of area (MELLO, 2016).

The production of fine table grapes (Vitis vinifera) predominates in Paraná. They are mainly cultivated in the Northern region of the state (KISHINO and ROBERTO, 2007; POMMER, 2003). On a smaller scale, especially in the Southern region of the state, common or American (Vitis labrusca) grapevines are cultivated for later processing (KISHINO and ROBERTO, 2007). In the Southwest of Paraná, the main cultivars planted are Bordô (44\%), Niagara Branca and Niagara Rosada (35.08\%), Concord (8.92\%) and Isabel (3.8\%) (ZARTH et al., 2011).

American grapevines ( $V$. labrusca) form the varietal basis of Brazilian grape juice, being the cultivars Isabel, Bordô and Concord, the most important (TERRA et al., 2001). In the search for broadening the varieties and the processing period, some materials released in recent years by Embrapa Grape and Wine (Embrapa Uva e Vinho) are being disseminated in several production poles of the species, as the grapes 'BRS Rubea', 'BRS Cora', 'BRS Violeta' and 'BRS Carmem', which outstood due to their high levels of sugar and colored substances (CAMARGO et al., 2010).

A grapevine can adapt to different regions. However, the meteorological conditions influence the development, the productivity and the quality of the grapes, becoming a very important factor in defining the potentialities of grapevine cultivation in a certain region (TONNIETTO and MANDELLI, 2003). This fact justifies the studies on soil and climate adaptation of the conditions of humid subtropical climates (Cfa) from the southwest of Paraná, especially for varieties newly released to the market, which still lack information.

Thus, this study had as objective to evaluate the main yield components and chemical attributes of quality of grapes cultivated in Dois Vizinhos, Southwest of Paraná.

\section{Material and Methods}

This field study was conducted in the Fruit Growing sector of the Federal Technological University of Paraná,

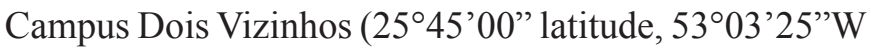
longitude). The climate of the region is humid subtropical (Cfa), according to the Köppen classification, with average annual temperature of $22^{\circ} \mathrm{C}$ in warmest months, and less than $18^{\circ} \mathrm{C}$ in colder months, showing average precipitation of 2,025 $\mathrm{mm}$ per year (ALVARES et al., 2013). The soil of this region is classified as Dystrophic Red Latosol (SANTOS et al., 2013).

Two agricultural harvests $(2015 / 2016$ and 2016/2017) were evaluated in cultivars Bordô, BRS Carmen, BRS Lorena, BRS Magna, BRS Rubea, BRS Violeta, Concord, Concord Clone 30, Isabel, Isabel Precoce, Moscato Bailey, Moscato Embrapa, Niagara Branca, Niagara Rosada e Seibel 5455. The plants evaluated were homogeneous within each variety, with medium vigor, and presented paltry production in some cultivars from previous years. The rootstock used was the Paulsen 1103.

Grapevines were implanted in August 2012, in a spacing of $1.5 \mathrm{~m} \times 2.3 \mathrm{~m}$. The conduction and support system of the plants was grape trellis with $1.8 \mathrm{~m}$ (height of the last wire) with four levels of wires and with the double intermediates being distanced $12 \mathrm{~cm}$ from each other. The production branches or arms were pruned back to two buds each and maintained in unilateral single cordon 0.9 $\mathrm{m}$ above the ground.

The grapevine collection was handled according to the precepts of agroecological production. The soil was kept permanently covered by the cultivation of winter (Avena strigosa, Vicia sativa L. and Raphanus sativus L.) and summer (Canavalia ensiformis) cover plants. The fertilization maintenance of plants consisted of using vegetable ash, an organic compound and natural phosphate (Yorin), based on soil (in both years) and leaf (only in the second harvest) analysis. The pest and disease control was based on mixtures (Bordeaux and Viçosa) and copper hydroxide (Supera), applied, alternately, every two or three weeks, depending on environmental conditions. After winter pruning on August 07, 2015 and August 17, 2016, a lime sulfur mixture with association to mineral oil was applied.

During the harvest, the number of bunches per plant and the fresh biomass of bunches $(\mathrm{g})$ were obtained through their weighing on semi-analytical scale. Production $(\mathrm{kg} /$ plant) and productivity ( $\mathrm{t} / \mathrm{ha}$ ) were estimated based on these data, in which: $\mathrm{kg} / \mathrm{plant}=$ number of bunches/plant $\times$ fresh biomass of bunches and ton $/ \mathrm{ha}=\mathrm{kg} / \mathrm{plant} \times$ number of plants/ha (2898). The grapes were harvested based on the soluble solids content $\left(\geq 16^{\circ} \mathrm{Brix}\right)$. 
Immediately after the harvest, through manual crushing of four berries in 10 representative bunches by experimental unit ( 40 berries in total), a sample of juice from cultivars was extracted to evaluate soluble solids (SS) contents, $\mathrm{pH}$ and titratable acidity (TA); in addition, the SS/TA (ratio) was achieved. To obtain TA contents (\%), the $10 \mathrm{~mL}$ samples of juice $+90 \mathrm{~mL}$ of distilled water were titrated with $0.1 \mathrm{~N} \mathrm{NaOH}$ until reaching $\mathrm{pH} 8.1$. The titration was conducted with the aid of a digital $\mathrm{pH}$ meter.

The experimental design was completely randomized with four repetitions, being the experimental unit formed by four plants (two border plants and two useful plants destined to assessment), in a bi-factor model, being the first factor the cultivars, and the second one the agricultural harvests. Analysis of variance was applied (ANOVA) to the data and, when significant, the means were grouped according to Scott \& Knott test at 5\% probability of error, with the statistical program Genes (CRUZ, 2006).

\section{Results and Discussion}

Considering the variable "number of bunches per plant", there was no interaction between cultivars and harvests; however, the factor "cultivar" had significant effect, with differences between the means of cultivars (Table 1). In the mean of years-harvests, cultivars with most bunches per plant were Seibel 5455 (33.0), Isabel Precoce (31.1) and BRS Violeta (29.1). The year-crop with greater numbers of bunches per plant, according to the mean of cultivars, was 2016/2017, mainly because the environmental conditions, especially of temperature in winter and spring, were more favorable than the previous year.

As for "fresh biomass of bunches", there was significant interaction among the factors evaluated. In year-harvest 2015/2016, the noteworthy cultivars were BRS Lorena (43.2), BRS Rubea (63.4), Moscato Bailey (61.0), Moscato Embrapa (65.8) e Seibel 5455 (50.8), which did not differ statistically between themselves, but differed from the other cultivars. In the first year-harvest, the general occurrence of small bunches were observed, given that the low age of plants (three years) may have influenced these results. There was also an excess of precipitation in the period preceding the crop, causing rottenness of berries and attacks of wasps and bees, which consume the juice of berries, promoting their dehydration, abscission or dry.

In year-harvest 2016/2017, there was statistical difference for fresh biomass from bunches among cultivars evaluated. We can note that for most cultivars, the biomass was above $100 \mathrm{~g}$. The cultivar Rúbea BRS (220.8) had the highest biomass, being greater than that described by Camargo and Dias (1999), who report that this cultivar has small bunches weighing $100 \mathrm{~g}$. However, we must emphasize that the biomass of bunches also depends on the age of plants, number of bunches/plant, as well as fertilization, phytosanitary treatments and meteorological conditions during its development.

The lack of winter cold on the grapevine delays the sprouting of buds, decreases the branches, causes little uniformity and low development of branches and delays the maturation of berries (CAMARGO and ZANUZ, 1997), in which there can even occur late productions of low quality and lesser quantity (SOZIM et al., 2007), as observed in the first year-harvest of this research.

Camargo et al. (2008) report that BRS Carmen has medium bunches that weigh around $200 \mathrm{~g}$, and Camargo et al. (2005) report that the BRS Violeta has medium bunches of $150 \mathrm{~g}$. This proves that the climatic conditions in the year-harvest of 2015/2016 were not favorable to grapevine cultivation. The bunches with fresh biomass were below the described in the literature, with the cultivar BRS Carmen reaching only $16 \mathrm{~g}$ and the BRS Violeta, $25.8 \mathrm{~g}$, different from what happened in the second year-harvest, in which the same cultivars reached mean biomasses of bunches similar to the values obtained by the aforementioned authors, $131.2 \mathrm{~g}$ and $142.6 \mathrm{~g}$, respectively.

The cultivar Bordô had no productions in the two years-harvests evaluated (Table 1). According to Miotto (2012), when compared with other American cultivars, the Bordo has inconstant production and has no high productivity, due to the "desavinho", a physiological disorder characterized by the fall of flowers and young berries that, when intense, makes the bunch loose or failed. According to the author, "desavinho" can be caused by environmental, genetic and phytosanitary factors, as well as by cultivation management.

According to Pavanello e Botelho (2012), the production of bunches from the Bordô cultivar on the rootstock Paulsen 1103, in the 2006-2007 harvest, under soil and climate conditions of the city of Guarapuava, Paraná state, Brazil, was null. For these authors, the hypothesis is that the Bordo cultivar is not compatible with this rootstock.

There was interaction between the factors evaluated for the variable "production" ( $\mathrm{kg} / \mathrm{plant})$ (Table 1). The cultivars Seibel 5455 (1.32) and Isabel Precoce $(0.65)$ had the highest production per plant in the 2015/2016 harvest. The other cultivars did not differ statistically between them. A paltry production was obtained in this harvest. The mean of production of grapevines in this harvest was only $0.33 \mathrm{~kg} /$ plant. In the year-harvest 2016/2017, the cultivars with greater production were Seibel 5455 (6.13), BRS Violeta (5.57) and Isabel Precoce (4.12), which did not differ statistically from each other. Thus, the year-harvest 2016/2017, in addition to the plants being less young, provided more favorable climatic conditions for production of grapevines. 
There was interaction between the factors evaluated for the variable "productivity" (ton/ha). In the year-harvest 2015/2016, the cultivar Seibel 5455 (3.83) was the most productive. In the year-harvest 2016/2017, the most productive cultivars were Seibel 5455 (17.76), BRS Violeta (16.14) and Isabel Precoce (11.94), without statistical differences among them. The productivities obtained by these three cultivars in the year-harvest 2016/2017 can be considered regular to good when taking into account young grapevines (four years), given that in the previous year-harvest the mean productivities were very low (Table 1 ).

Regarding the chemical attributes, there was interaction among factors evaluated for the soluble solids (SS) content (Table 2). According to the Brazilian legislation (Brasil, 2004), which provides the identity and quality standards for grape juice, the minimum SS content of $100 \%$ grape juice is $14^{\circ}$ Brix.

The cultivars that reached the highest SS contents in the year-harvest 2015/2016 were Niagara Branca (17.6), BRS Rubea, Moscato Embrapa (16.6), Moscato Bailey (16.3), BRS Violeta (15.8), BRS Carmen (15.5) and Isabel Precoce (15.1), statistically differing from others. In the year-harvest 2016/2017, there was statistical difference among cultivars, in which we noted that only the cultivar Seibel 5455, who presented the lowest SS content (13.9), for the second consecutive year, differed statistically from others (Table 2). It is worth mentioning that this cultivar had a cycle of 136 days, the largest among cultivars evaluated, factor that, when associated with the pluviometric precipitation (data not shown), possibly prevented the full ripening of the grape to the moment of the harvest.

We also observed that there was significant interaction between cultivars and years-harvests for the pH of different grapes. In the year-harvest 2015/2016, the highest $\mathrm{pH}$ values were found in cultivars Moscato Bailey (3.2) and Niagara Rosada (3.2), which differed statistically from the others. The latter obtained $\mathrm{pH}$ indexes below the recommended for juice preparation, because, according Rizzon et al. (2004), the ideal pH must be between 3.1 and 3.3. These data indicate that the grapes were not entirely ripe at the time of harvest and/or that the environmental conditions were not favorable to their ripening.

In the year-harvest $2016 / 2017,60 \%$ of cultivars had the $\mathrm{pH}$ within the range recommended for juice preparation. In some, such as Moscato Bailey (3.5) and Niagara Branca (3.4), the $\mathrm{pH}$ was slightly above the recommended and, in others, as in Isabel (3.0), BRS Lorena (2.9) and Seibel 5455 (2.9), the index was slightly lower, but within the mean (Table 2). According to Santana et al. (2008), the $\mathrm{pH}$ is related to gustatory characteristics of juices and can be influenced mainly by genetic variability, environmental conditions and by processing.
For titratable acidity (AT), there was interaction between cultivars and years-harvest. In both yearsharvests the cultivate Seibel 5455 achieved the highest TA index. The lowest values were found in cultivars as Niagara Branca (0.72) and Niagara Rosada (0.70) in 2015/2016, and Concord (0.64) in 2016/2017 (Table 2).

Manfroi et al. (2004) reported that at the beginning of ripening the main acids of the grapevine (tartaric and malic) are synthesized by leaves and berries still green. Therefore, in this period, berries have a high TA content. However, the concentration of acids decreases as the ripening evolves because the energy demand in respiration increases, as well as the dilution of juice.

The ratio shows that in the year-harvest 2015/2016, cultivars with the highest and lowest ratio were the Niagara Branca (24.9) and the Seibel 5455 (5.9), respectively, given that Niagara Rosada (18.8) and BRS Violeta (16.3) also had desirable ratios. In the year-harvest 2016/2017, cultivars that achieved the highest and greatest ratios were Concord (22.9), Isabel (20.7), Niagara Rosada (19.0), Niagara Branca (18.3) and Moscato Embrapa (17.7), without statistical differences among them (Table 2).

According to the Brazilian legislation (Brazil, 2004), the minimum value recommended of ratio for preparation of $100 \%$ grape juices with quality and good potential of conservation is 15 . Despite being very productive, the cultivar Seibel 5455 had the lowest ratio because it did not present good quality attributes for preparation of $100 \%$ grape juices.

A sunnier ripening period with higher temperatures determine greater degradation of malic acid through respiratory combustion and, consequently, less acidic and more ripe grapes. That is, very low acidity contents and very high soluble solids contents generate very high ratios, undermining the quality and reducing the storage time of juices (RIZZON and SGANZERLA, 2007).

The ratio is one of the parameters used to determine grape ripeness and its oenological quality. Thus, its use as index for grape ripening must be careful, because a SS increase not always corresponds to a same TA reduction (RIZZON and MIELE, 2002). It represents the balance between sweet and sour taste of juices, therefore being their indicative of quality (PEZZI and FENOCCHIO, 1976). 
Table 1. Number of bunches per plant, fresh biomass of bunch, production and productivity of grape in different cultivars of grapevines. UTFPR-DV. Dois Vizinhos, PR, 2017.

\begin{tabular}{|c|c|c|c|c|c|c|c|}
\hline \multirow[t]{2}{*}{ Cultivar/Year } & \multirow{2}{*}{$\begin{array}{c}\text { Bunches/ } \\
\text { plant }\end{array}$} & \multicolumn{2}{|c|}{$\begin{array}{l}\text { Fresh biomass of } \\
\text { bunches (g) }\end{array}$} & \multicolumn{2}{|c|}{ Production (kg/plant) } & \multicolumn{2}{|c|}{$\begin{array}{l}\text { Productivity } \\
\text { (ton/ha) }\end{array}$} \\
\hline & & $15 / 16$ & $16 / 17$ & $15 / 16$ & $16 / 17$ & $15 / 16$ & $16 / 17$ \\
\hline Bordô & $0.75 \mathrm{c}^{*}$ & $(-)$ & $(-)$ & $(-)$ & $(-)$ & $(-)$ & $(-)$ \\
\hline BRS Carmem & $13.0 \mathrm{~b}$ & $16.0 \mathrm{bB}^{*}$ & $131.2 \mathrm{bA}$ & $0.08 \mathrm{bB} *$ & $2.64 \mathrm{bA}$ & $0.24 \mathrm{cB}^{*}$ & $7.66 \mathrm{bA}$ \\
\hline BRS Lorena & $13.2 \mathrm{~b}$ & $43.2 \mathrm{aB}$ & $151.2 \mathrm{bA}$ & $0.42 \mathrm{bB}$ & $2.42 \mathrm{bA}$ & $1.23 \mathrm{bB}$ & $7.02 \mathrm{bA}$ \\
\hline BRS Magna & $11.7 \mathrm{~b}$ & $10.0 \mathrm{bB}$ & $108.5 \mathrm{cA}$ & $0.10 \mathrm{bB}$ & $2.00 \mathrm{bA}$ & $0.10 \mathrm{cB}$ & $5.78 \mathrm{bA}$ \\
\hline BRS Rúbea & $8.4 \mathrm{c}$ & $63.5 \mathrm{aB}$ & $220.8 \mathrm{aA}$ & $0.15 \mathrm{bB}$ & $3.27 \mathrm{bA}$ & $0.43 \mathrm{cB}$ & $9.48 \mathrm{bA}$ \\
\hline BRS Violeta & $29.1 \mathrm{a}$ & $25.8 \mathrm{bB}$ & $142.6 \mathrm{bA}$ & $0.48 \mathrm{bB}$ & $5.57 \mathrm{aA}$ & $1.39 \mathrm{bB}$ & $16.14 \mathrm{aA}$ \\
\hline Concord & $7.5 \mathrm{c}$ & $26.3 \mathrm{bB}$ & $109.8 \mathrm{cA}$ & $0.13 \mathrm{bB}$ & $1.13 \mathrm{cA}$ & $0.38 \mathrm{cB}$ & $3.28 \mathrm{cA}$ \\
\hline Concord Clone 30 & $13.0 \mathrm{~b}$ & $15.5 \mathrm{bB}$ & $74.2 \mathrm{dA}$ & $0.12 \mathrm{bB}$ & $1.37 \mathrm{cA}$ & $0.34 \mathrm{cB}$ & $3.97 \mathrm{cA}$ \\
\hline Isabel & $17.7 \mathrm{~b}$ & $24.6 \mathrm{bB}$ & $91.7 \mathrm{dA}$ & $0.29 \mathrm{bB}$ & $2.19 \mathrm{bA}$ & $0.85 \mathrm{cB}$ & $6.35 \mathrm{bA}$ \\
\hline Isabel Precoce & $31.1 \mathrm{a}$ & $24.1 \mathrm{bB}$ & $111.3 \mathrm{cA}$ & $0.65 \mathrm{aB}$ & $4.12 \mathrm{aA}$ & $1.88 \mathrm{bB}$ & $11.94 \mathrm{aA}$ \\
\hline Moscato Bailey & $8.1 \mathrm{c}$ & $61.0 \mathrm{aB}$ & $129.0 \mathrm{bA}$ & $0.31 \mathrm{bB}$ & $1.63 \mathrm{cA}$ & $0.90 \mathrm{cB}$ & $4.72 \mathrm{cA}$ \\
\hline Moscato Embrapa & $6.4 \mathrm{c}$ & $65.8 \mathrm{aA}$ & $65.5 \mathrm{dA}$ & $0.26 \mathrm{bA}$ & $0.62 \mathrm{cA}$ & $0.75 \mathrm{cA}$ & $1.80 \mathrm{cA}$ \\
\hline Niagara Branca & $12.0 \mathrm{~b}$ & $34.8 \mathrm{bB}$ & $86.5 \mathrm{dA}$ & $0.31 \mathrm{bB}$ & $1.38 \mathrm{cA}$ & $0.90 \mathrm{cB}$ & $4.00 \mathrm{cA}$ \\
\hline Niagara Rosada & $9.6 \mathrm{c}$ & $19.2 \mathrm{bB}$ & $79.7 \mathrm{dA}$ & $0.12 \mathrm{bB}$ & $0.97 \mathrm{cA}$ & $0.35 \mathrm{cB}$ & $2.81 \mathrm{cA}$ \\
\hline Seibel 5455 & $33.0 \mathrm{a}$ & $50.8 \mathrm{aB}$ & $154.0 \mathrm{bA}$ & $1.32 \mathrm{aB}$ & $6.13 \mathrm{aA}$ & $3.83 \mathrm{aB}$ & $17.76 \mathrm{aA}$ \\
\hline Mean & 14.3 & 33.6 & 118.3 & 0.33 & 2.53 & 0.96 & 7.34 \\
\hline CV (\%) & 26.0 & \multicolumn{2}{|c|}{28.5} & \multicolumn{2}{|c|}{42.2} & \multicolumn{2}{|c|}{36.3} \\
\hline
\end{tabular}

* Means followed by the same lowercase letter in columns and uppercase in rows, not differing among themselves by the Scott \& Knott test at $5 \%$ probability of error; (-) absence of production.

Table 2. Soluble solids contents, $\mathrm{pH}$, titratable acidity and ratio of different cultivars of grapevines. UTFPR-DV, Dois Vizinhos, PR, 2017.

\begin{tabular}{|c|c|c|c|c|c|c|c|c|}
\hline \multirow{2}{*}{ Cultivar/Year } & \multicolumn{2}{|c|}{ SS ( $\left({ }^{\circ}\right.$ Brix) } & \multicolumn{2}{|c|}{ pH } & \multicolumn{2}{|c|}{ TA (\%) } & \multicolumn{2}{|c|}{ Ratio (SS/TA) } \\
\hline & $15 / 16$ & $16 / 17$ & $15 / 16$ & $16 / 17$ & $15 / 16$ & $16 / 17$ & $15 / 16$ & $16 / 17$ \\
\hline Bordô & - & - & - & - & - & - & - & - \\
\hline BRS Carmem & $15.5 \mathrm{aA}^{*}$ & $16.4 \mathrm{aA}$ & $2.2 \mathrm{cB}^{*}$ & $3.2 \mathrm{aA}$ & $1.52 \mathrm{bA}^{*}$ & $1.39 \mathrm{cB}$ & $10.4 \mathrm{dA}^{*}$ & $11.8 \mathrm{cA}$ \\
\hline BRS Lorena & $13.3 \mathrm{bB}$ & $16.3 \mathrm{aA}$ & $2.4 \mathrm{cB}$ & $2.9 \mathrm{bA}$ & $1.38 \mathrm{bB}$ & $1.63 \mathrm{bA}$ & $10.0 \mathrm{dA}$ & $10.1 \mathrm{cA}$ \\
\hline BRS Magna & - & $14.7 \mathrm{a}$ & - & $3.1 \mathrm{~b}$ & - & $1.40 \mathrm{c}$ & - & $10.5 \mathrm{c}$ \\
\hline BRS Rúbea & $16.6 \mathrm{aA}$ & $16.2 \mathrm{aA}$ & $2.7 \mathrm{cB}$ & $3.1 \mathrm{bA}$ & $1.52 \mathrm{bA}$ & $1.17 \mathrm{~dB}$ & $11.0 \mathrm{~dB}$ & $13.8 \mathrm{bA}$ \\
\hline BRS Violeta & $15.8 \mathrm{aA}$ & $16.1 \mathrm{aA}$ & $2.9 \mathrm{bB}$ & $3.3 \mathrm{aA}$ & $1.00 \mathrm{dA}$ & $1.00 \mathrm{dA}$ & $16.3 \mathrm{bA}$ & $16.3 \mathrm{bA}$ \\
\hline Concord & - & $14.7 \mathrm{a}$ & - & $3.3 \mathrm{a}$ & - & $0.64 \mathrm{f}$ & - & $22.9 \mathrm{a}$ \\
\hline Concord C1.30 & - & $15.3 \mathrm{a}$ & - & $3.3 \mathrm{a}$ & - & $0.91 \mathrm{e}$ & - & $17.0 \mathrm{~b}$ \\
\hline Isabel & $14.4 \mathrm{bB}$ & $16.7 \mathrm{aA}$ & $2.7 \mathrm{cB}$ & $3.0 \mathrm{bA}$ & $1.08 \mathrm{dA}$ & $0.81 \mathrm{eB}$ & $13.6 \mathrm{cB}$ & $20.7 \mathrm{aA}$ \\
\hline Isabel Precoce & $15.1 \mathrm{aA}$ & $16.4 \mathrm{aA}$ & $2.5 \mathrm{cB}$ & $3.1 \mathrm{bA}$ & $1.56 \mathrm{bA}$ & $1.11 \mathrm{~dB}$ & $9.7 \mathrm{~dB}$ & $14.9 \mathrm{bA}$ \\
\hline Mosc. Embrapa & $16.6 \mathrm{aA}$ & $16.6 \mathrm{aA}$ & $2.3 \mathrm{cB}$ & $3.3 \mathrm{aA}$ & $1.20 \mathrm{cA}$ & $1.20 \mathrm{dA}$ & $13.5 \mathrm{cA}$ & $13.9 \mathrm{bA}$ \\
\hline Moscato Bailey & $16.3 \mathrm{aA}$ & $16.2 \mathrm{aA}$ & $3.2 \mathrm{aA}$ & $3.5 \mathrm{aA}$ & $1.28 \mathrm{cA}$ & $0.97 \mathrm{eB}$ & $12.9 \mathrm{cB}$ & $17.7 \mathrm{aA}$ \\
\hline Niagara Branca & $17.6 \mathrm{aA}$ & $17.1 \mathrm{aA}$ & $2.5 \mathrm{cB}$ & $3.4 \mathrm{aA}$ & $0.72 \mathrm{eA}$ & $0.88 \mathrm{eA}$ & $24.9 \mathrm{aA}$ & $18.3 \mathrm{aB}$ \\
\hline Niagara Rosada & $13.5 \mathrm{bB}$ & $16.1 \mathrm{aA}$ & $3.2 \mathrm{aA}$ & $3.2 \mathrm{aA}$ & $0.70 \mathrm{eA}$ & $0.85 \mathrm{eA}$ & $18.8 \mathrm{bA}$ & $19.0 \mathrm{aA}$ \\
\hline Seibel 5455 & $13.6 \mathrm{bA}$ & $13.9 \mathrm{bA}$ & $2.5 \mathrm{cB}$ & $2.9 \mathrm{bA}$ & $2.30 \mathrm{aA}$ & $2.35 \mathrm{aA}$ & $5.9 \mathrm{eA}$ & $6.0 \mathrm{dA}$ \\
\hline Mean & 15.3 & 15.9 & 2.6 & 3.1 & 1.29 & 1.16 & 13.1 & 14.4 \\
\hline CV (\%) & \multicolumn{2}{|c|}{6.9} & \multicolumn{2}{|c|}{7.4} & \multicolumn{2}{|c|}{3.7} & \multicolumn{2}{|c|}{14.0} \\
\hline
\end{tabular}

* Means followed by the same lowercase letter in columns and uppercase in rows. not differing among themselves by the Scott \& Knott test at $5 \%$ probability of error; (-) data absence due to absence of production and/or crop. 


\section{Conclusions}

Under soil and climate conditions of Dois Vizinhos, Southwest of Paraná, Brazil, this study concluded that cultivars Seibel 5455, BRS Violeta and Isabel Precoce are the most productive.

The grapevine cultivars BRS Rubea, BRS Violeta, Isabel, Moscato Embrapa, Moscato Bailey, Niagara Branca and Niagara Rosada produced grapes with desirable soluble solids contents, $\mathrm{pH}$ and acidity for the preparation of $100 \%$ grape juices of quality.

The year-harvest 2016/2017 had more favorable environmental conditions for sprouting, flowering and production of grapevines.

\section{Acknowledgments}

We thank the Postgraduate Program in Agroecosystems and the Coordination for the Improvement of Higher Education Personnel (CAPES) by granting the masters scholarship to the main author of the research.

\section{References}

ALVARES, C.A.; STAPE, J.L.; SENTELHAS, P.C.; GONÇALVES, J.L. de M.; SPAROVEK. G. Köppen's climate classification map for Brazil. Meteorologische Zeitschrift, Berlin, v.22, n.6, p.711-728, 2013.

BRASIL. Ministério da Agricultura e do Abastecimento. Portaria $\mathrm{n}^{\circ} 55$, de 27 de julho de 2004 . Normas referentes à complementação dos padrões de identidade e qualidade do vinho e dos derivados da uva e do vinho. Disponível em: <www.agricultura.gov.br>. Acesso: 02 jan. 2017.

CAMARGO, U.A.; DIAS, M.F. BRS Rúbea. Bento Gonçalves: Embrapa Uva e Vinho, 1999. 4p. (Comunicado Técnico, 33).

CAMARGO, U.A.; MAIA, J.D.G.; NACHTIGAL, J.C. BRS Violeta, nova variedade de uva para suco e vinho de mesa. Bento Gonçalves: Embrapa Uva e Vinho, 2005. 8p. (Comunicado Técnico, 63).

CAMARGO, U.A.; MAIA, J.D.G.; RITSCHEL, P.S. BRS Carmem, nova variedade de uva tardia para suco. Bento Gonçalves: Embrapa Uva e Vinho, 2008. 8p. (Comunicado Técnico, 84).
CAMARGO, U.A.; MAIA, J.D.G.; RITSCHEL, P.S. Embrapa Uva e Vinho. In: RITSCHEL, P.; SEBBEN, S.S. Novas variedades brasileiras de uva. Bento Gonçalves: Embrapa Uva e Vinho, 2010. 64p.

CAMARGO, U.A.; ZANUZ, M.C. Moscato Embrapa: nova variedade para a elaboração de vinho branco. Bento Gonçalves: Embrapa Uva e Vinho, 1997. 4p. (Comunicado Técnico, 24).

CRUZ, C.D. Programa Genes: estatística experimental e matrizes. Viçosa: Universidade Federal de Viçosa. 285p. 2006.

IBGE - Instituto Brasileiro de Geografia e Estatística. Levantamento sistemático da produção agrícola (2015). Rio de Janeiro, 2015. Disponível em: <https:// sidra.ibge.gov.br/home/lspa>. Acesso em: 07 mar. 2017.

KISHINO, A.Y.; ROBERTO, S.R. Tratos culturais. In: KISHINO, A.Y.; CARVALHO, S.L. C.; ROBERTO, S.R. Viticultura tropical. Londrina: IAPAR, 2007. p. 171-202.

MANFROI, V.; MIELE, L.; RIZZON, L.A.; BARRADAS, C.I.N.; SOUZA, P.V.D. Evolução da maturação da uva 'Cabernet Franc' conduzida no sistema lira aberta. Revista Ciência Agrotécnica, Lavras, v.28, p.306-313, 2004.

MELLO, L.M.R. de. Desempenho da vitivinicultura brasileira em 2015. Bento Gonçalves: Embrapa Uva e Vinho, 2016. 5p. (Comunicado Técnico, 191).

MELLO, L.M.R. de. Panorama da produção de uvas e vinhos no Brasil. Bento Gonçalves: Embrapa Uva e Vinho, 2017. 3p. (Informe Técnico).

MIOTTO, L.C.V. Avaliação agronômica de clones de videira cultivar Bordô (Vitis labrusca L.) no sul de Minas Gerais. 2012. 79f. Dissertação (Mestrado) Universidade Federal de Lavras, Lavras, 2012.

PAVANELLO, A.P.; BOTELHO, R.V. Estádios fonológicos e produtividade de diferentes cultivares de videira para vinificação sob cobertura plástica. Guarapuava: Unicentro, 2012. Disponível em: < http:// xc.pl/YCl6w7Xh >. Acesso em: 23 ago. 2017.

PEZZI, G.M.; FENOCCHIO, P. Estudo analítico dos sucos de uva comerciais. Pesquisa Agropecuária Brasileira, Brasília, DF, v.11, n.12, p.11-13, 1976. 
POMMER, C.V. Uva: tecnologia de produção, póscolheita, mercado. In: POMMER, C.V. Introdução. Porto Alegre: Cinco Continentes, 2003. p.11-35.

RIZZON, L.A.; MIELE, A. Avaliação da cv. Cabernet Sauvignon para elaboração de vinho tinto. Revista Ciência e Tecnologia de Alimentos, Campinas, v.22, n.2, p.192-198, 2002.

RIZZON, L.A.; SGANZERLA, V.M.A. Ácidos tartárico e málico no mosto de uva em Bento Gonçalves-RS. Revista Ciência Rural, Santa Maria, v.37, n.3, 2007.

SANTANA, M.T.A. Caracterização de diferentes marcas de suco de uva comercializados em duas regiões do Brasil. Revista Ciência Agrotecnológica, Lavras, v.32, n.3, p.882-886, 2008.

SANTOS, H.G. dos, ALMEIDA, J.A.; OLIVEIRA, J.B.; LUMBRERAS, J.F.; ANJOS, L.H.C.; COELHO, M.R.; JACOMINE, P.K.T.; CUNHA, T.J.F.; OLIVEIRA, V.A. Sistema brasileiro de classificação de solos. 3.ed. Brasília, DF: Embrapa, 2013. 353 p.
SOZIM, M.; FERREIRA, F.P.; AYUB, R.A.; BOTELHO, R.V. Época de poda e quebra de dormência em videiras cv. Niagara Rosada. Ciências Agrárias, Londrina, v.28, n.2, p.201-206, 2007.

TERRA, M.M.; POMMER, C.V.; PIRES, E.J.P.; RIBEIRO, I.J.A.; GALLO, P.B.; PASSOS, I.R.S. Produtividade de cultivares de uvas para suco sobre diferentes porta-enxertos IAC em Mococa-SP. Revista Brasileira de Fruticultura, Jaboticabal, v.23, n.2, p.382386. 2001.

TONIETTO, J.; MANDELLI, F. Uvas viníferas para processamento em regiões de clima temperado. Sistema de produção, 4. Versão eletrônica. 2003. Disponível em: $<\underline{\text { https:// }}$ sistemasdeproducao.cnptia.embrapa.br/FontesHTML/ Uva/UvasViniferasRegioesClimaTemperado/.> . Acesso em: 28 set. 2016.

ZARTH, N.A.; CITADIN, I.; PERONDI, M.Â.; DONAZZOLO, J. Perfil sócio-econômico da vitivinicultura na região sudoeste do Paraná. Synergismus Scyentifica UTFPR, Pato Branco, v.6, n.1, p.1-10, 2011. 